\title{
Customers Satisfaction towards Housing Finance of Commercial Banks in Chennai City
}

\section{P. Vimala}

\begin{abstract}
Housing generally refers to the social problem of ensuring that members of society have a home in which to live, whether it is a house or some other kind of dwelling or shelter. Globalization of banking industry has sparred a new era of international expansion of financial markets. In India, the Banking Regulation Act was passed in the parliament in 1949 and the globalization of banking sector was open for private bankers and foreign bankers to banking industry.

The monopolies of public sector banks were broken. Little formal research appears to have been conducted which attempts to ascertain the various key concepts in housing finance. An attempt is made in this research paper to analyze the various factors which lead to customer's satisfaction and this sector is effective in their performance level and there is much more to be achieved.

Well framed questionnaires were circulated in different parts of Chennai city and the data from 100 respondents were selected from 5 banks of both public and private sectors are analyzed. Now present scenario, with the entry of commercial banks in the industry, the competition has become severe. The commercial banks are bringing the various strategies of performance to succeed the ultimate goal of customers' satisfaction and this sector is effective in their performance level and there is much more to be achieved.
\end{abstract}

Keywords : Awareness, Commercial Banks, Customer Satisfaction and Housing Finance.

\section{INTRODUCTION}

$\mathrm{O}_{\text {ne of the significant aspects of budding housing }}$ finance business in India has been the increasing participation of the commercial banks. The product of choice for banks because of their attractive profitability, low risk weight, low delinquency history and the ease of processing of Housing loans. Mortgages explosive growth are recorded by All Banks which has vastly expanded the market. Housing loans have also provided further incentive to go for increased housing activity given in budgets.

The focus of this research is the study of housing finance in commercial banks including a comparison of schemes across banks with respect to their EMIs (Equated Monthly Installments) and on the basis of other terms and conditions, including value added services/additional incentives provided by the banks to home loan customers. In addition to the main objective, to ascertain public attitude towards housing finance has also been undertaken.

Banks have been especially keen on housing loans grabbing a substantial market share in the mortgage business. Banks despite being a late entrant, have overtaken Housing Finance Companies in the Home Loan Market. Banks have entered almost all the segments in retail finance and are also gaining share from NBFC's (Non- Banking Finance Companies).

\section{OBJECTIVES OF STUDY}

- To examine that awareness level of the respondents with regard to housing finance in commercial banks.

- To study the factors influencing the respondents to prefer public or private sector commercial banks.

- To measure the opinions of the respondents regarding their satisfaction with various services rendered towards housing by commercial banks.

- To assess and critically evaluate the comparison of customer's satisfaction of commercial banks towards housing finance.

- To observe the problems of customers as well as suggestions for the development of housing finance activity.

\section{A. Hypotheses}

- Housing Finance in commercial banks creates more awareness in the society.

- Commercial Banks contributions to overall improvement in housing sector

- All private commercial banks provide equal amount of services and similar products.

- Customers are fully satisfied with the housing finance by commercial banks.

- There is no significance in social - economic factors, housing finance borrowers attitude towards private commercial bank's housing schemes.

\section{METHODOLOGY}

The present study is a analytical and empirical one which evaluates the public and private sector banks providing the services to their customers on the viewpoint of housing finance customers in Chennai, which form the primary sources. Structured questionnaires and well-balanced direct interview method have been used to collect data from primary and secondary sources. 


\section{Customers Satisfaction Towards Housing Finance of Commercial Banks in Chennai City}

\section{CUSTOMERS' SATISFACTION ON HOUSING LOAN}

Comparison of banking sectors with respect to respondents' satisfaction

To test the significant difference between the banking sectors with respect to the satisfaction of respondents towards housing finance, independent samples t-test is applied to identify the significant difference between the banking sectors with respect to the satisfaction. The following null hypotheses are framed:

$\mathbf{H}_{0}$ 4: There is no relavant difference between the banking sectors with respect to the satisfaction towards;

- Loan process.

- Banking services.

- Expenses of loan.

- Convenient banking.

- Services of the banker.

Table shows the results of comparison of banking sectors with respect to respondent's satisfaction.

Table - 1: Comparison of banking sectors with respect to customers' satisfaction

\begin{tabular}{|c|c|c|c|c|c|}
\hline Variables & Bank & No & Mean & S D & t-value \\
\hline \multirow{2}{*}{ Customers' satisfaction towards loan process } & Public sector & 72 & 21.63 & 1.804 & \multirow{2}{*}{$2.355^{*}(\mathrm{p}=.012)$} \\
\hline & Private sector & 28 & 20.91 & 1.868 & \\
\hline \multirow{2}{*}{ Customers' satisfaction towards Banking services } & Public sector & 72 & 38.38 & 2.612 & \multirow{2}{*}{$2.470 *(\mathrm{p}=.011)$} \\
\hline & Private sector & 28 & 37.20 & 2.413 & \\
\hline \multirow{2}{*}{ Customers' satisfaction towards expenses of loan } & Public sector & 72 & 29.49 & 1.917 & \multirow{2}{*}{$3.909 * *(\mathrm{p}=.003)$} \\
\hline & Private sector & 28 & 28.87 & 2.355 & \\
\hline \multirow{2}{*}{$\begin{array}{l}\text { Customers' satisfaction regarding convenient } \\
\text { banking }\end{array}$} & Public sector & 72 & 29.29 & 1.981 & \multirow{2}{*}{$3.171^{* *}(\mathrm{p}=.009)$} \\
\hline & Private sector & 28 & 28.95 & 1.557 & \\
\hline \multirow{2}{*}{$\begin{array}{l}\text { Customers' satisfaction towards services of the } \\
\text { banker }\end{array}$} & Public sector & 72 & 57.58 & 5.208 & \multirow{2}{*}{$3.187 * *(\mathrm{p}=.008)$} \\
\hline & Private sector & 28 & 56.37 & 4.008 & \\
\hline
\end{tabular}

\section{A. Customers' satisfaction towards loan process}

The obtained ' $\mathrm{t}$ ' value is 2.355 and it is significant at $5 \%$ level. The value indicates that there is relavant difference between the banking sectors with respect to the satisfaction towards loan process on housing finance. Therefore, the formulated hypothesis is that "There is no relavant difference between the banking sectors with respect to the satisfaction towards loan process" is rejected.

Further, the mean table indicates that the customer's got housing finance in public sector banks have scored highest mean value of 21.63 and the lowest mean value was scored by the respondents got housing finance from private sector banks (20.91). This shows that, the respondents got housing finance in public sector banks are having better satisfaction towards loan process than the respondents got housing finance from private sector banks.

\section{B. Customers' satisfaction towards banking services}

The table ' $t$ ' shows 2.470 and it is significant at 5\% level. The value indicates that there is significant difference between the banking sectors with respect to the satisfaction towards banking services on housing finance. Therefore, the formulated hypothesis is that "There is no remarkable difference between the banking sectors with respect to the satisfaction towards banking services" is rejected.

Therefore, the mean table shows that the applicant's got housing finance in public sector banks have scored highest mean value of 38.38 and the lowest mean value was scored by the respondents got housing finance in private sector banks (37.20). This shows that, the respondents got housing finance in public sector banks are having better satisfaction towards banking services than the respondents got housing finance in private sector banks.

\section{Customers' satisfaction towards expenses of loan}

The ' $t$ ' value is 3.909 and it is significant at $1 \%$ level. The value indicates that there is significant difference between the banking sectors with respect to the satisfaction towards expenses of loan on housing finance. Therefore, the formulated hypothesis is that "There is no notable difference between the banking sectors with respect to the satisfaction towards expenses of loan" is rejected.

As well as, the mean table explains that the public got housing finance in public sector banks have scored highest mean value of 29.49 and the lowest mean value was scored by the respondents got housing finance from private sector banks (28.87). This shows that, the respondents got housing finance from public sector banks are more satisfied towards expenses of loan than the respondents got housing finance in private sector banks.

\section{Customers' satisfaction towards convenient banking}

The table value of ' $t$ ' is 3.171 and it is significant at $1 \%$ level. The value indicates that there is significant difference between the banking sectors with respect to the satisfaction towards convenient banking 
on housing finance.

Therefore, the formulated hypothesis is that "There is no significant difference between the banking sectors with respect to the satisfaction towards convenient banking" is rejected.

Above the mean table views that the respondents got housing finance in public sector banks have scored highest mean value of 29.29 and the lowest mean value was scored by the respondents got housing finance in private sector banks (28.95). This shows that, the respondents got housing finance in public sector banks are having more satisfaction towards convenience in banking than the respondents got housing finance in private sector banks.

\section{E. Customers' satisfaction towards services of the banker}

The ' $t$ 'value shows 3.187 and it is significant at $1 \%$ level. The value indicates that there is significant difference between the banking sectors with respect to the satisfaction towards services of the banker on housing finance. Therefore, the formulated hypothesis is that "There is no significant difference between the banking sectors with respect to the satisfaction towards services of the banker" is rejected.

In the mean table indicates that the person's got housing finance in public sector banks have scored highest mean value of 57.58 and the lowest mean value was scored by the respondents got housing finance in private sector banks (56.37). This shows that, the respondents got housing finance in public sector banks are having better satisfaction towards services of the banker than the respondents got housing finance in private sector banks.

\section{Comparison of banking sectors with respect to respondents' satisfaction}

- The problems through delay in sanction and disbursement on housing finance are not observed. The respondents got housing finance in private sector banks are facing more problems through delay in sanction and disbursement than the respondents got housing finance in public sector banks.

- The difficult arises in inadequate guidance by the bank on housing finance are observed. The respondents got housing finance in private sector banks are facing more problems through inadequate guidance by the bank as compared with the respondents got housing finance in public sector banks.

- The major confusion is cumbersome procedure on housing finance are observed. The respondents got housing finance in private sector banks are facing more problems through cumbersome procedure than the respondents got housing finance in public sector banks.

- The lack of interest shown by the officials on housing finance are observed. The respondents got housing finance in private sector banks are facing more problems through lack of interest shown by the officials as compared with the respondents got housing finance from public sector banks.

- And so difficult to get security/surety for loan on housing finance are observed. The respondents got housing finance in private sector banks are facing more problems through difficult to get security/surety for loan and the respondents got housing finance in public sector banks.

\section{SUGGESTIONS}

\section{A. -To the Customers}

- The customers should avoid impulse taking housing loans, care should be taken to analyze the various attributes and select a banker that suits their requirements.

- The customers should not carry away by the rosy statements given by the banking companies about the rate of interest.

- Documentation of complaints from customers are very essential, as it becomes a record.

- The customers should acquire knowledge of the relevant features of various housing schemes before taking loans.

- The customers should acquire knowledge on the relevant laws relating to banking.

- Awareness of the current rate of interest introduced to housing loans by RBI is mandatory.

\section{B. -To the banking company}

- The private bankers should make trustworthy relationship with the customers customer to have new experience.

- The private bankers should conduct awareness programmes to educate customers on the importance of housing. This will help in increasing the customer penetration.

- The customers should be treated with empathy and their queries and complaints must be answered and taken seriously.

- Safe and quick means of processing housing loans should be ensured.

- Customers exist survey should be conducted to identify reasons for the pre closure of housing loans.

- An appropriate system of feedback should be adopted.

- A comprehensive team with financial experts must design housing schemes that suit even the low income group to come for housing loans.

- Employees are to be trained and empowered in order to offer better customer service.

- Effective Customer Relationship Management (CRM) should be developed to attract customers.

- An effective method should be developed to create awareness and tap the vast untapped potential.

- Transparency and ethics in conduct of business should be adopted. The disbursement of housing loans should be speeded up and done with utmost benefit to the borrowers. 


\section{Customers Satisfaction Towards Housing Finance of Commercial Banks in Chennai City}

\section{CONCLUSION}

The opening up of the banking sectors to the private bankers have definitely been a positive development. The privatization in the banking sectors have made one beneficiary, "The Customer" happy. The social, demographic and psychographic trends in liberalized era are much formulated for the growth of banking sectors.

The privatization of the insurance sectors has created many opportunities and challenges to the insurers.

The first challenge comes from the market turbulence. The second challenge comes from rapidly changing customers expectations. The last challenge is in the form of organizational constraints. Thus, the competition while offering sample opportunities to companies to widen the horizon of the market are also subjected to serious challenges due to increased sensitiveness of customers to the quality of customer services.

\section{REFERENCES}

1. www.rbi.org

2. www.tn.gov.in

3. www.nhb.in

\section{AUTHOR PROFILE}

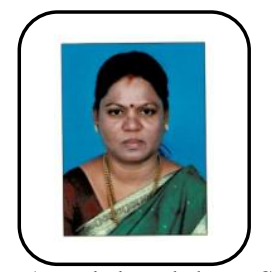

P.Vimala, M.Com.,M.Phil.,Ph.D Working as Assistant Professor, Department of Commerce, Anna Adarsh College for Women, Chennai-40. Worked as the Head of the Department of Commerce in Jaya College of Arts and Science for more than ten Years. Working as an Assistant Professor in Commerce in Anna Adarsh college for women for more than eight years. Published many articles in various journals and Attended workshops, Symposiums and national international Conferences. 